Research Article

\title{
Effects of Sediment Dredging on Nutrient Release and Eutrophication in the Gate-Controlled Estuary of Northern Taihu Lake
}

\author{
Xi Chen, ${ }^{1}$ Yanhua Wang $\mathbb{D}^{1},{ }^{1,2,3}$ Tian Sun, ${ }^{1}$ Yu Huang, ${ }^{1}$ Yan Chen, ${ }^{1}$ Mingli Zhang, \\ and Chun $\mathrm{Ye} \mathbb{D}^{4}$ \\ ${ }^{1}$ School of Geography, Nanjing Normal University, Nanjing 210023, China \\ ${ }^{2}$ Key Laboratory of Virtual Geographic Environment, Nanjing Normal University, Ministry of Education, Nanjing 210023, China \\ ${ }^{3}$ Jiangsu Center for Collaborative Innovation in Geographical Information Resource Development and Application, \\ Nanjing 210023, China \\ ${ }^{4}$ Chinese Research Academy of Environmental Sciences, Beijing 10002, China
}

Correspondence should be addressed to Yanhua Wang; wangyanhua@njnu.edu.cn and Chun Ye; yechun@craes.org.cn

Received 21 July 2020; Revised 17 December 2020; Accepted 31 December 2020; Published 19 January 2021

Academic Editor: Pedro Avila P rez

Copyright $\odot 2021 \mathrm{Xi}$ Chen et al. This is an open access article distributed under the Creative Commons Attribution License, which permits unrestricted use, distribution, and reproduction in any medium, provided the original work is properly cited.

\begin{abstract}
Estuarine zones are regarded as the ecotones connecting the rivers and lakes. Sediment dredging is a conventional treatment technology that is widely used to remove the internal loading in estuarine zones worldwide. However, what is the characteristic of nutrient release in the gate-controlled estuary and how long this practice is effective are still unclear. Hence, sediment and water samples were collected from dredged and undredged regions around the gate-controlled estuary of northern Taihu Lake for laboratory experiments, in which they were subjected to different temperatures, depths, and disturbance levels. The total nitrogen (TN) and total phosphorus (TP) concentrations of the dredged region were lower than those from the undredged region under stable hydrodynamic conditions. A high dynamic release rate $(R)$ of nutrients in the dredged sediments $\left(R_{\mathrm{TN}}=164.75 \mathrm{mg} / \mathrm{m}^{2} \cdot \mathrm{d}\right.$ and $R_{\mathrm{TP}}=5.83 \mathrm{mg} / \mathrm{m}^{2} \cdot \mathrm{d}$ ) existed under dynamic release conditions (stirring speeds: 90 and $120 \mathrm{r} / \mathrm{min}$ ). The effect of disturbance and temperature on release rate and nutrient form was completely different for the static and dynamic release cases. The nutrient loads from dynamic release were 4-17 times greater than those from static release. For unstable hydrodynamic conditions, the release rate from the bottom sediment exceeded that from the surface sediment in the undredged region. These results indicated that, under stable hydrodynamic conditions, dredging improves long-term water quality. However, dredging alone in unstable hydrodynamic conditions may not remove the potential risk of internal release in the long term. Specific ecological and engineering measures should be combined with dredging practice to restore estuary habitats and minimize the release of internal pollutants.
\end{abstract}

\section{Introduction}

Sediment is considered an important nutrient source and/or sink in waterbodies [1-3]. When hydrodynamic conditions are stable and nutrients and other pollutants are introduced into lakes by river systems, sediments can serve as a sink through the adsorption, sedimentation, and mineralization of particles $[4,5]$. However, these natural conditions are continually changed by wind-wave action, flooding/flushing, dissolved oxygen, $\mathrm{pH}$, water temperature, and anthropogenic activities [6-9], which may cause nutrients to be released from sediments and suspended matter [10]. Sediment disturbance is predominantly caused by wind-wave action, shipping, and bioturbation $[11,12]$. Sediment disturbance changes the turbidity of overlying water and affects plant photosynthesis and the eutrophic status of overlying water [13]. Nutrient release from sediment occurs frequently in large shallow lakes, especially in the estuarine zones $[3,14]$, because the water-sediment interface is readily disturbed by the shear forces from currents and waves due to the shallow water depth and long fetch $[15,16]$. Field 
investigations have revealed that dynamic nutrient release is more realistic than static release because sediments and suspended matter are frequently disturbed by wind waves $[17,18]$. The internal phosphorus (P) and ammonia/ammonium $\left(\mathrm{NH}_{3} /\right.$ $\mathrm{NH}_{4}{ }^{+}$) loads induced by dynamic release are 8-10 times greater than those induced by gradient diffusion $[19,20]$. In several case studies, nutrient loads induced by endogenous pollution sources have even been found to exceed exogenous sources [21, 22].

Despite the strengthening of environmental pollution control measures, which have effectively reduced the levels of exogenous pollutants, eutrophication issues in shallow lakes have still not been alleviated [11, 17]. Large and harmful algal blooms of increasing magnitude and frequency occur worldwide [23]. Therefore, the contribution of internal nutrient release to eutrophication has received considerable attention globally [24]. Different types of sediment dredging, including dry dredging and wet dredging, have been widely used to reduce the total internal nutrient loading [25, 26]. However, the effectiveness of dredging depends on multiple factors, such as the available technology, operation time, dredging scope, and dredging depth [27-30]. Previous studies have reported that dredging reduces the total nutrient loading in the short term [31, 32], but it also has negative impacts on the aquatic habitat such as increased water turbidity, biodiversity reduction, and secondary pollution $[27,33,34]$.

Gates have been widely constructed in many areas for power generation and flood control, as well as for irrigation in estuary, river, reservoir, and lake systems [35]. However, this practice changes the material exchange conditions, blocks biological corridors, and breaks the hydrological connectivity between rivers and lakes, causing significant hydrodynamic variation and generating negative impacts on estuarine systems [36]. Hence, gate construction may also impact on internal nutrient release and, ultimately, discount the dredging effectiveness of eutrophication. The uncertainties associated with dredging and gate construction have resulted in the formation of the following questions: (1) what are the characteristics of release rate and nutrient form around the gate in response to disturbance and temperature variations? (2) Does the release rate have a significant difference between dredged and undredged regions? (3) Does the sediment dredging have a long-term beneficial effect on the restoration of the aquatic environment in estuaries or not?

The long-term impact on water quality due to the presence of a gate and dredging in a hypereutrophic estuary is unclear. Most previous studies have focused on the sediments inside the lake over short time intervals $[3,11,12]$, while gate-controlled and hypereutrophic estuaries have received insufficient attention. An estuary is an important part of the lake ecosystem, which connects lakes and rivers [37]. It is extremely susceptible to the large amounts of terrestrial pollutants discharged into it by rivers [38]. With rapid urbanization and population growth, environmental problems, such as eutrophication, the death of aquatic plants, and the degradation of ecosystem functions, have occurred $[39,40]$. Estuary regions are closer to the center of anthropogenic activity than the center of a lake [36, 41], and many contaminants are preferentially deposited within these small areas. Therefore, estuary sediment has a large potential for internal release. If the total internal release rate is estimated based only on the sediment inside the lake, the contribution of internal release to eutrophication is underestimated. Gate construction changes the natural hydrodynamic structure in the estuary $[35,36]$. The sedimentation environment may be disturbed by different flow velocities near the gate, especially when it is opened. It is therefore vitally important to understand the release characteristics of internal nutrients between dredged and undredged sediment and implement measures to suppress the risk of internal release in a gate-controlled estuary under different conditions.

The main objectives of this study were to (1) understand the basic properties of water and sediment between the dredged and undredged regions of a gate-controlled estuary, (2) explore the difference of nutrient release rate and form responding to disturbances and temperature variations around the gate, and (3) evaluate the effects of sediment dredging on nutrient release and eutrophication.

\section{Materials and Methods}

2.1. Study Area. Taihu Lake is a large shallow, circular lake $\left(29^{\circ} 55^{\prime}-32^{\circ} 19^{\prime} \mathrm{N}, 118^{\circ} 50^{\prime}-121^{\circ} 55^{\prime} \mathrm{E}\right)$ located in the lower reaches of the Yangtze River Delta, China. It is the thirdlargest freshwater lake in China, with a surface area of $2338 \mathrm{~km}^{2}$. The mean water depth is $1.9 \mathrm{~m}$ [42]. The levels of eutrophication in this lake have increased from mild to severe over the past three decades $[43,44]$. Since the highly publicized 2007 drinking water crisis in Wuxi City, Jiangsu Province $[3,17]$, many measures have been implemented to reduce external nutrient inputs into the lake (e.g., point pollution control, factory relocation, sediment dredging, and wetland construction) [45]. The flow of external nutrients has been controlled to some extent, but eutrophication and cyanobacteria blooms still occur every year in the estuary [46].

Gonghu Bay (Figure 1) is located in a low-terrain, dense river network, in which water has been heavily polluted in the last three decades [42]. To prevent the inflow of external sewage into the bay (Figure S1), in recent decades, approximately $85 \%$ of the rivers located in Wuxi city that are connected to Gonghu Bay have been closed off through the construction of a gate (length: 5-30 m; height: 3-10 m). In the region's subtropical monsoon climate, approximately $75 \%$ of the prevailing wind is from the southeast in summer. Under natural conditions, the direction of water flow is from downtown to the lake. Due to the regulation of hydrodynamic forces by the gate, three typical river systems (see [9] for details) were investigated in this study. Field observation and published data $[3,30]$ have shown that water flow rates in the lake region are in the range of $0.10-0.70 \mathrm{~m} / \mathrm{s}$. In the river region, the barrier of the gate restricts the water flow rate to less than $0.10 \mathrm{~m} / \mathrm{s}$. When the gate is opened, the maximum instantaneous velocity of water flow is more than $0.9 \mathrm{~m} / \mathrm{s}$. In front of the gate, a large ecological restoration and dredging project (top $30 \mathrm{~cm}$ ) commenced in 2011 (Figure 1). 


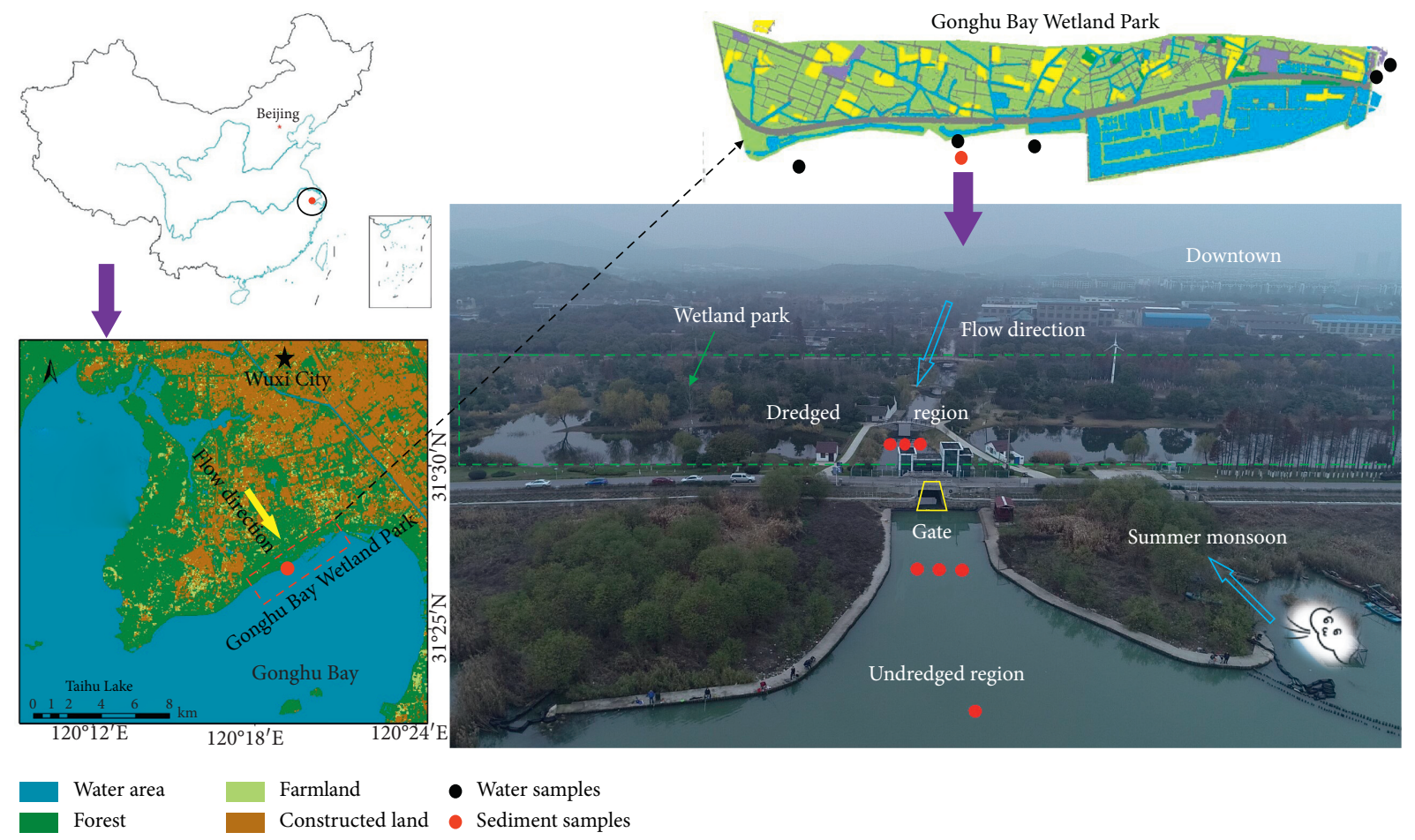

Figure 1: Location of sampling sites.

As part of this project, Gonghu Bay Wetland Park (area: $18.5 \mathrm{~km}^{2}$; length: $24 \mathrm{~km}$ ) was built along the lakeside to improve the ecological environment [47]. All the dredge spoils were immediately transported to a dedicated dumping site approximately $10 \mathrm{~km}$ away from the dredged region for silt solidification, heavy metal determination, treatment to render contaminants harmless, and resource reuse [28, 47]. Following these measures, secondary pollution from the dredged spoils has been avoided in the dredged regions.

2.2. Sample Collection and Laboratory Experiment. In the study area, the estuary was divided into two parts by the construction of a gate (Figure 1). In front of the gate, the river sediment was dredged. On the other side of the gate, there has been no dredging of the lake sediment. Water samples, surface sediment samples $(0-10 \mathrm{~cm}$ depth), and sediment cores $(30-45 \mathrm{~cm}$ depth) were collected in the estuary between June 2018 and April 2019 in Gonghu Bay. To reduce sampling errors, duplicate water samples were taken seasonally with a Plexiglas water sampler. Sediment samples (0-10 cm depth) were collected four times per year using a grab bucket. After rubble and litter were removed, the samples were transferred to a sealable plastic bag. Ten sediment cores (30-45 cm depth) were collected by a gravity sediment sampler fitted with an $8.6 \mathrm{~cm}$ diameter polyvinyl chloride (PVC) tube. Among the collected samples, one $45 \mathrm{~cm}$-long sediment core was cut into three equal parts for the analysis of the dynamic nutrient release at different depths. The other sediment cores were used to examine the release characteristics under different conditions. All samples were transported to a laboratory immediately after collection. The water samples were stored at $4^{\circ} \mathrm{C}$ for further physicochemical analysis. Half of each sediment sample was stored at $-20^{\circ} \mathrm{C}$, and the other half was freeze-dried at $20 \mathrm{~Pa}$ and $-50^{\circ} \mathrm{C}$.

In the experiment, three stirring speeds $(0,90$, and $120 \mathrm{r} / \mathrm{min})$, two temperatures $\left(20\right.$ and $\left.30^{\circ} \mathrm{C}\right)$, and three sediment depths $(0-15,16-30$, and $31-45 \mathrm{~cm})$ were applied based on the actual conditions in the estuary (Table S1). To minimize uncertainty with the quality of overlying water over time and to easily understand the mechanism of nutrient release in response to disturbance and temperature variations, all the overlying water was replaced by ultrapure water. First, overlying water was siphoned off, and then $1 \mathrm{~L}$ of ultrapure water was introduced using the same method. The experiment then started after $24 \mathrm{~h}$ with a static condition to reduce the potential interference of ultrapure water on nutrient release rate in response to disturbance and temperature variations in the short term. Three magnitudes of disturbance were applied to the dredged and undredged sediment cores at 30 and $20^{\circ} \mathrm{C}$, respectively. The largest degree of disturbance $(120 \mathrm{r} / \mathrm{min})$ and water temperature $\left(30^{\circ} \mathrm{C}\right)$ was applied to sediment cores from different depths. A $0.25 \mathrm{~L}$ volume of water was removed from the tube by suction for use in the physicochemical parameter experiment, and the same volume of ultrapure water was immediately added. During the experimental period, overlying water samples were collected after $1,3,6,9,12,24,30,36,48,60,72,84,96,108,120,132$, 144 , and $156 \mathrm{~h}$. The volume of evaporated water was replenished after each sampling.

All physicochemical parameters were analyzed according to standard methods [48]: total nitrogen (TN), total 
dissolved nitrogen (TDN), total phosphorus (TP), total dissolved phosphorus (TDP), ammonium-nitrogen $\left(\mathrm{NH}_{4}{ }^{+}-\right.$ $\mathrm{N})$, nitrate-nitrogen $\left(\mathrm{NO}_{3}{ }^{-}-\mathrm{N}\right)$, total inorganic nitrogen (TIN), total organic nitrogen (TON), and total dissolved organic carbon (TOC). The TN (standard HJ 636-2012), TDN (standard HJ 636-2012), TP (standard GB 11893-89), TDP (standard GB 11893-89), $\mathrm{NH}_{4}{ }^{+}-\mathrm{N}$ (standard GB 747887), and $\mathrm{NO}_{3}{ }^{-}-\mathrm{N}$ (standard $\mathrm{HJ} / \mathrm{T} 346-2007$ ) concentrations were determined by ultraviolet spectrophotometry (UV3600, Shimadzu, Japan). The TOC concentration (standard GB 13193-91) was measured using a TOC analyzer (SSM500A, Shimadzu, Japan) [48].

2.3. Calculation of Nutrient Release. The dynamic release rate $(R)$ of nutrients from sediment was calculated using a previously reported method, which has been modified by several researchers $[1,49]$. The following equation (1) was used:

$$
R=\frac{\left[V\left(c_{n}-c_{0}\right)+\sum_{i=1}^{n} V_{i}\left(c_{i-1}-c_{a}\right)\right]}{A \cdot t},
$$

where $R$ is the dynamic release rate $\left(\mathrm{mg} /\left(\mathrm{m}^{2} \cdot \mathrm{d}\right)\right)$ of nutrients; $V$ is the volume of the water sample in the simulator $(\mathrm{L}) ; c_{n}$ and $c_{i-1}$ are the nutrient concentrations in the water samples at the $n^{\text {th }}$ and $(i-1)^{\text {th }}$ samplings $(\mathrm{mg} / \mathrm{L})$, respectively; $c_{0}$ is the initial nutrient concentration $(\mathrm{mg} / \mathrm{L}) ; V_{i}$ is the sampling volume (L); $c_{a}$ is the nutrient concentration of raw water $(\mathrm{mg} / \mathrm{L}) ; t$ is the release time $(\mathrm{h}) ;$ and $A$ is the area of the water-sediment interface $\left(\mathrm{m}^{2}\right)$.

2.4. Statistical Analysis. All the experimental data and yearbook data (1990-2018) were analyzed using Microsoft Excel 2016 software (Microsoft, USA). A Pearson correlation coefficient analysis and paired sample $t$-tests were used to explore the difference of nutrient release between the dredged and undredged region. The principal component analysis (PCA) was applied to explore the effects of disturbance, temperature, and depth on nutrient release rates and chemical forms. Two significance levels of statistical significance $\left({ }^{*} p<0.05\right.$ and $\left.{ }^{*} p<0.01\right)$ were defined. Twoway repeated measures ANOVA was used to account for the effect of time under disturbance and temperature variation (Table S2). Regression analysis was applied to estimate the release rate responding to disturbance level and temperature vibration (Figure 2). The risk posed by the water quality and sediment was calculated by the correction of the Nemerow pollution index (CNPI) and composite pollution index (CPI) $[50,51]$. The classification standard of water quality based on the CNPI is presented in Table S3. The TN losses from external pollution sources were calculated by the nonpoint source pollution equation $[52,53]$.

\section{Results and Discussion}

3.1. Basic Properties of Water and Sediments in the Dredged and Undredged Regions. In the surface waterbodies, the average TN, TP, $\mathrm{NH}_{4}{ }^{+}-\mathrm{N}, \mathrm{NO}_{3}{ }^{-}-\mathrm{N}$, and TOC concentrations of (Table 1) in the dredged region (spring-winter, 2018) were
$1.37 \pm 0.17, \quad 0.08 \pm 0.01, \quad 0.34 \pm 0.15, \quad 0.19 \pm 0.11, \quad$ and $16.38 \pm 2.73 \mathrm{mg} / \mathrm{L}$, respectively. In the undredged region, the average $\mathrm{TN}, \mathrm{TP}, \mathrm{NH}_{4}{ }^{+}-\mathrm{N}, \mathrm{NO}_{3}{ }^{-}-\mathrm{N}$, and TOC concentrations were $1.82 \pm 0.37,0.10 \pm 0.04,0.48 \pm 0.34,0.24 \pm 0.13$, and $14.40 \pm 1.70$, respectively. In terms of the spatial variation, except for TOC, the CNPI values of the water and sediment samples in the undredged region $(\mathrm{CNPI}=1.36)$ were higher than those in the dredged region $(\mathrm{CNPI}=1.04)$. In terms of the temporal distribution, except for the TP and $\mathrm{NH}_{4}{ }^{+}-\mathrm{N}$ levels in the dredged region, the nutrient concentrations during the wet season (summer and autumn) were much lower than during the dry season (spring and winter), whereas the opposite phenomenon was observed in the undredged region. Similar chemical composition characteristics were observed in both organic and inorganic matter in surface water. $\mathrm{NH}_{4}{ }^{+}-\mathrm{N}$ was the major contributor to TIN, accounting for approximately $75 \%$ of the total. Clear seasonal differences in TOC, TN, and TP concentrations were found in both dredged and undredged sediments. The average TN, TP, and TOC concentrations in surface sediments were $4.35 \pm 1.05,0.16 \pm 0.02$, and $47.30 \pm 10.48 \mathrm{~g} / \mathrm{kg}$, respectively. The pollution risk of the sedimentary nutrients in both dredged and undredged regions was classed as heavy pollution $(\mathrm{CPI}=2.88)$.

A better water quality was observed in the dredged region, but its CNPI values were still classed as moderate pollution $(\mathrm{CNPI}>1)$, indicating that other sources of nutrients may be present in this area. The field investigation and data analysis revealed that gate construction in the estuary may have aggravated the pollution level. The gate blocks some of the connectivity between the rivers and lakes, preventing nutrient cycling, material transportation, and energy exchange $[36,38,54]$. Previous studies found that sediment dredging may temporarily (less than two years) reduce the internal load of sediments $[29,34,40]$. Sediment nutrients may again pose a moderate pollution risk after several years due to the proximity of farmland and residential areas to the upstream region of the lake or estuary.

External pollution sources, including fertilizer applications, livestock, aquaculture, and domestic sewage, have been controlled to some extent following the water crisis of 2007. However, the area of the impervious surface surrounding the lake has increased from $78.77 \mathrm{~km}^{2}$ in 2007 to $104.88 \mathrm{~km}^{2}$ in 2018 due to urbanization, which has greatly increased the surface runoff $[37,55]$. Furthermore, due to limited and incomplete sewerage systems for rainwater and sewage diversion, many pollutants are directly or indirectly discharged into the local rivers by runoff, especially during heavy rainfall events $[37,56]$. Because of the barriers presented by the gate in the estuary, nutrients have gradually accumulated in the river and eventually in the sediments. The internal loading in the dredged sediment has therefore increased over time, and the TP concentration even exceeded that of the undredged region. Therefore, gate construction would be expected to improve the water quality in the lake (undredged region).

The exogenous nutrient locked in the river by the gate cannot readily enter the lake. Therefore, endogenous 


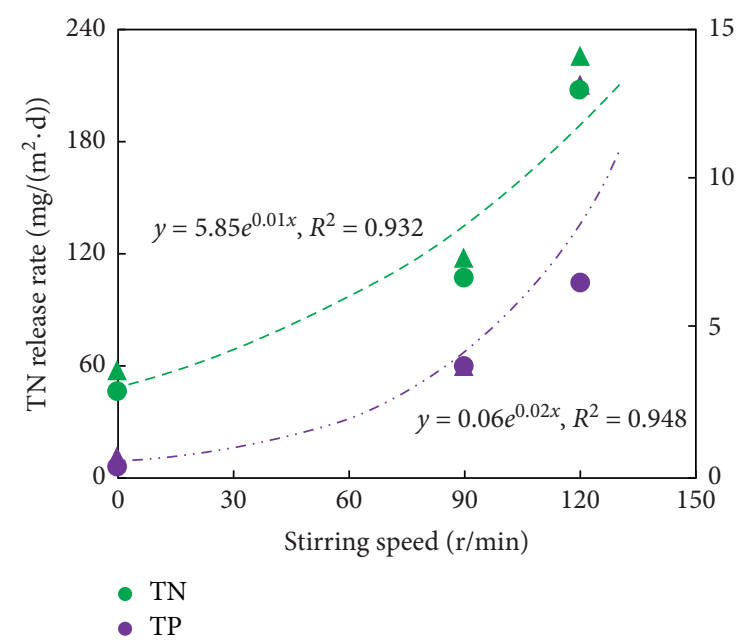

(a)

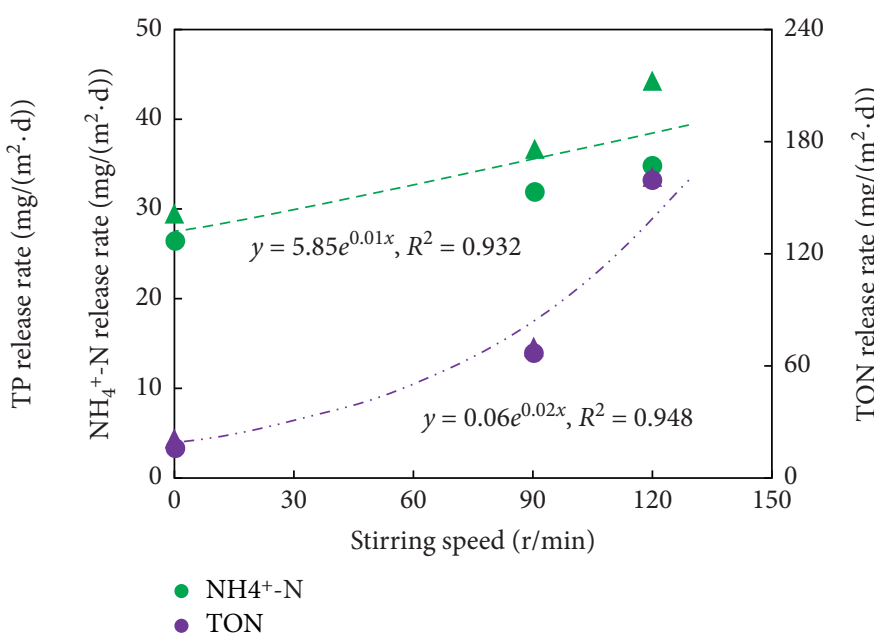

(b)

Figure 2: Regression analysis of the release rate responding to disturbance and temperature vibrations. Note: the solid triangle and circle represent high-temperature $\left(30^{\circ} \mathrm{C}\right)$ and low-temperature $\left(20^{\circ} \mathrm{C}\right)$ conditions, respectively.

TABle 1: Nutrient concentrations in the dredged and undredged regions.

\begin{tabular}{|c|c|c|c|c|c|c|c|c|c|}
\hline \multirow{2}{*}{\multicolumn{2}{|c|}{ Sampling site/season }} & \multicolumn{4}{|c|}{ Dredged region } & \multicolumn{4}{|c|}{ Undredged region } \\
\hline & & Spring & Summer & Autumn & Winter & Spring & Summer & Autumn & Winter \\
\hline \multirow{5}{*}{$\begin{array}{l}\text { Surface } \\
\text { water (mg/ } \\
\text { L) }\end{array}$} & $\mathrm{TN}$ & $1.33 \pm 0.49$ & $1.42 \pm 0.94$ & $1.15 \pm 0.40$ & $1.56 \pm 0.64$ & $1.78 \pm 0.64$ & $2.29 \pm 0.56$ & $1.38 \pm 0.06$ & $1.81 \pm 0.36$ \\
\hline & $\mathrm{TP}$ & $0.07 \pm 0.02$ & $0.10 \pm 0.82$ & $0.07 \pm 0.04$ & $0.08 \pm 0.08$ & $0.11 \pm 0$ & $0.16 \pm 0$ & $0.07 \pm 0.01$ & \pm 0.02 \\
\hline & $\mathrm{NH}_{4}{ }^{+}-\mathrm{N}$ & $0.52 \pm 0.24$ & $0.41 \pm 0.06$ & & & & & & 0.11 \\
\hline & $\mathrm{NO}_{3}{ }^{-}-\mathrm{N}$ & $0.22 \pm 0.13$ & $0.09 \pm 0.004$ & $0.12 \pm 0.06$ & $0.33 \pm 0.24$ & $0.27 \pm 0.06$ & $0.09 \pm 0.02$ & $0.20 \pm 0.03$ & $0.40 \pm 0.10$ \\
\hline & TOC & $19.79 \pm 0.84$ & $13.20 \pm 1.24$ & $16.82 \pm 1.28$ & $15.70 \pm 1.46$ & $15.98 \pm 1.85$ & $12.07 \pm 0.87$ & $15.23 \pm 1.99$ & $14.31 \pm 2.49$ \\
\hline \multirow{3}{*}{$\begin{array}{l}\text { Surface } \\
\text { sediment } \\
(\mathrm{g} / \mathrm{kg})\end{array}$} & $\mathrm{TN}$ & $2.99 \pm 1.52$ & $4.29 \pm 0.89$ & $3.19 \pm 1.52$ & $4.04 \pm 1.11$ & $4.39 \pm 1.62$ & $4.27 \pm 0.74$ & $5.58 \pm 2.30$ & $6.04 \pm 2.02$ \\
\hline & $\mathrm{TP}$ & $0.16 \pm 0.07$ & $0.15 \pm 0.01$ & $0.15 \pm 0.01$ & $0.15 \pm 0.02$ & $0.16 \pm 0.04$ & $0.19 \pm 0.04$ & $0.17 \pm 0.06$ & $0.19 \pm 0.12$ \\
\hline & TOC & $29.89 \pm 15.23$ & $42.94 \pm 8.91$ & $31.88 \pm 15.17$ & $40.43 \pm 11.06$ & $43.94 \pm 16.25$ & $42.68 \pm 7.38$ & $55.77 \pm 22.99$ & $60.44 \pm 20.21$ \\
\hline
\end{tabular}

pollution sources may be the main contributors to the ongoing eutrophic conditions in the estuary. The evaluated CPI indicated that nutrient levels in the sediment exceeded the severe pollution level $(\mathrm{CPI}=6.83)$. Sediment with a high background nutrient level presents a huge potential release risk, especially under unstable hydrodynamic conditions. Due to the reduction of wind speed caused by the high embankment and plant growth, sediment in the rivers (dredged region) was less disturbed than in the lakes (undredged region). This may be the main factor controlling the differences in nutrient distribution. The characteristics of nutrient release and how this process contributes to the differences in eutrophication between the dredged and undredged regions were then considered.

3.2. Static and Dynamic Releases in Dredged and Undredged Regions. Under conditions favouring static release, the release rate had a significantly positive correlation $\left(p_{\mathrm{TN}}=0.01\right.$ and $p_{\mathrm{TP}}<0.01$ ) with temperature (Figure 3 ). The average release rate at the higher temperature $\left(30^{\circ} \mathrm{C}\right)$ was 1.22 times the rate at the lower temperature $\left(20^{\circ} \mathrm{C}\right)$. Although the total nutrient loading released from the undredged sediment
$(\mathrm{TN}=7.43 \mathrm{mg}$ and $\mathrm{TP}=0.16 \mathrm{mg}$ ) was higher than that in the dredged sediment $(\mathrm{TN}=6.87 \mathrm{mg}$ and $\mathrm{TP}=0.08 \mathrm{mg})$, the $\mathrm{TN}$ release rate from the undredged sediment exceeded that of the dredged sediment during the middle and later periods of the simulation experiment. In terms of chemical composition, TIN contributed more $(65 \%)$ to TN than TON. It was found that $\mathrm{NH}_{4}{ }^{+}-\mathrm{N}$ was the major component of TIN, accounting for approximately $89 \%$ of the total. This indicates that, in the case of static release, nutrients were mainly present as dissolved inorganic salts. Compared with the dredged sediment, the undredged sediment had a greater potential risk of TP release.

At a water temperature of $30^{\circ} \mathrm{C}$, the static release rate of the dredged sediment exceeded that of the undredged sediment during the middle and later stages of the simulation experiment. This may have been caused by the high background values of sedimentary nutrients, providing sufficient raw material for static release. During the early stage of dynamic release, most of the released nutrients were diffused from interstitial water [11, 57], but the release rate later declined along with their depletion in interstitial water. It has been suggested that an elevated temperature of $30^{\circ} \mathrm{C}$ may accelerate the mineralization rate, thereby providing 


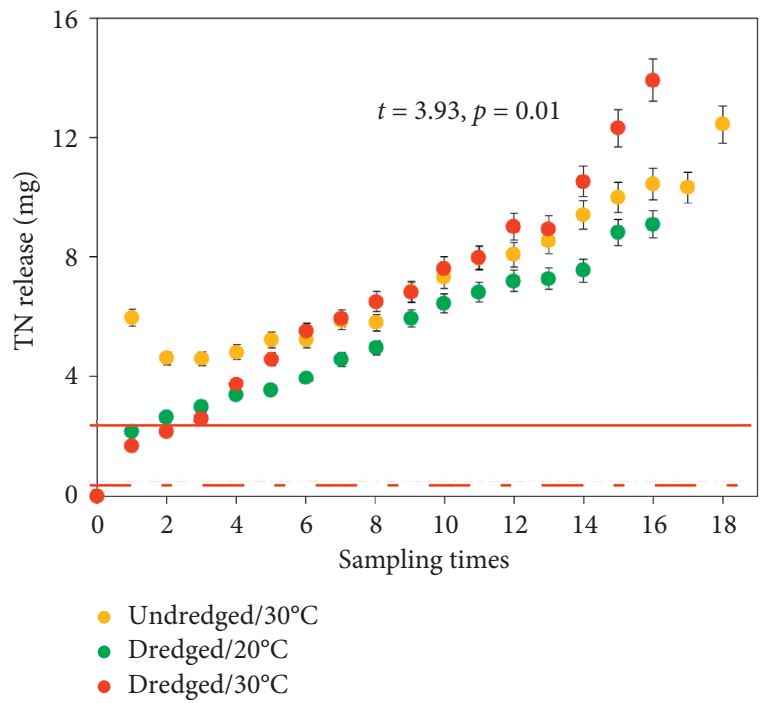

(a)

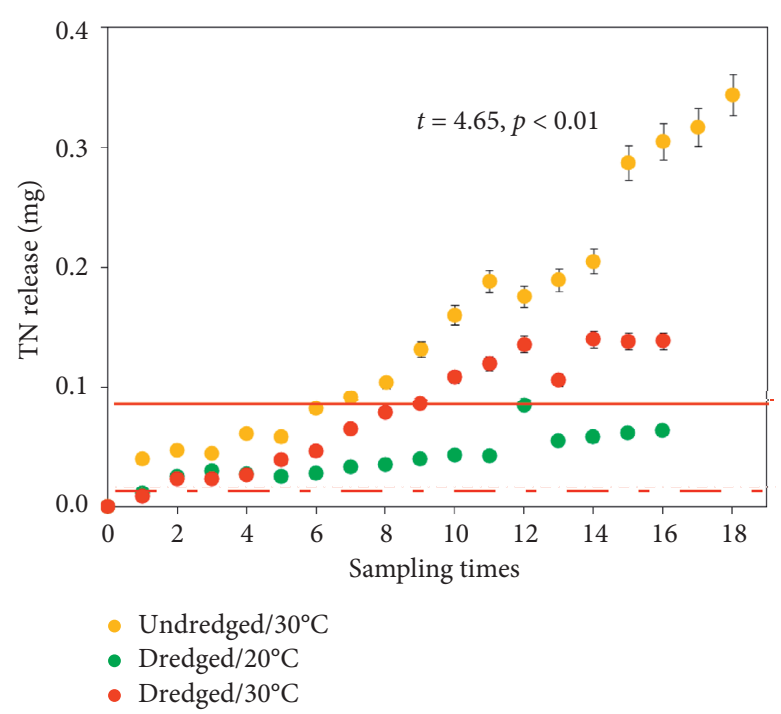

(b)

Figure 3: TN and TP static releases from dredged and undredged sediments. The broken line is the eutrophication threshold. The solid line is the nutrient concentration of overlying water in the field.

additional inorganic nutrients for release [58]. During the period of the simulation experiment, mineralization gradually reduced the contribution of TON to TN from $52 \%$ to $17 \%$.

There were no obvious differences between the dredged and undredged sediments in the case of dynamic release (Figure 4). Increases in the degree of disturbance and temperature greatly accelerated the rate of nutrient release. Disturbance had a much greater impact on the release rate than temperature variation (Table S2). At the same temperature, the dynamic release rate was 4-10 times the static release rate (Figure 2). For the same degree of disturbance, the release rate at $30^{\circ} \mathrm{C}$ was approximately 1.2 times the rate at $20^{\circ} \mathrm{C}$. Spatially, more nutrients were released from undredged sediments than from dredged sediments. An analysis of the chemical components revealed that the contribution of TIN to $\mathrm{TN}$ decreased with increased disturbance, whereas the opposite pattern was observed for TON. This indicated that, unlike static release, particulate organic nutrients were the main form of dynamically released nutrients.

Simulation experiments have revealed that large amounts of nutrients in sediments may be released from interstitial water due to dynamic disturbances by wind-wave action in the field [41]. Both dissolved and undissolved nutrients are released from the sediment and suspended matter. High water temperatures $\left(30^{\circ} \mathrm{C}\right)$ accelerate the rate of mineralization during dynamic release [58]. Over short time periods, mineralization contributes little to the total release load. Therefore, it has been surmised that the major contribution to the total released nutrients is from particulate matter. In this experiment, the release TIN loads increased over time, but were still far smaller than the TON loads (Figure 2). Given the high potential of the internal release rate under unstable hydrodynamic conditions, it appears that all of these processes may aggravate the eutrophication level.

Based on the CNPI evaluation method, the mean NPI values of static and dynamic releases in the dredged and undredged regions were calculated in a simulation experiment. The simulated dynamic release (Figure 5) indicated that the cumulative nutrient concentrations released from the sediment in both dredged (CNPI $=7.01 \pm 0.68)$ and undredged regions $(\mathrm{CNPI}=7.65 \pm 0.81)$ aggravated the levels of pollution risk in overlying water (from moderate to heavy pollution). Intense disturbance and high temperatures also accelerated the release of inorganic nutrients. Nutrients released in this form are suitable for absorption by algae [2], especially in spring and summer, which are the algae growth seasons. With increased water temperature and disturbance levels, internal release provides sufficient inorganic nutrient levels for algal growth and may play a crucial role in promoting large-scale algal blooms. Furthermore, the estuary enclosed by the gate has become a semiclosed area. The southeast monsoon in summer continuously transports a large mass of algae in the lake to the north shore (study area), further promoting the ecological deterioration of the estuary [50].

3.3. Characteristics of Nutrient Releases. Sediment resuspension and nutrient release due to wind waves represent complex fluid-sediment particle interactions. Theoretically, several factors have an impact on nutrient releases from sediments to overlying water in an estuary, such as hydrodynamic variability, diffusion (concentration gradient), sedimentary depth, water temperature, dissolved oxygen, and bioturbation $[6,8,9]$. This study identified the characteristics of nutrient release under different conditions. The results (Figure 6) showed that static and dynamic internal releases produced significantly different results. Inorganic nutrients accounted for approximately $65 \%$ of all nutrients released under static conditions (Figure 6(a)). Therefore, gradient diffusion was the main nutrient release pathway. Most of the nutrients were not released from the sediment, 


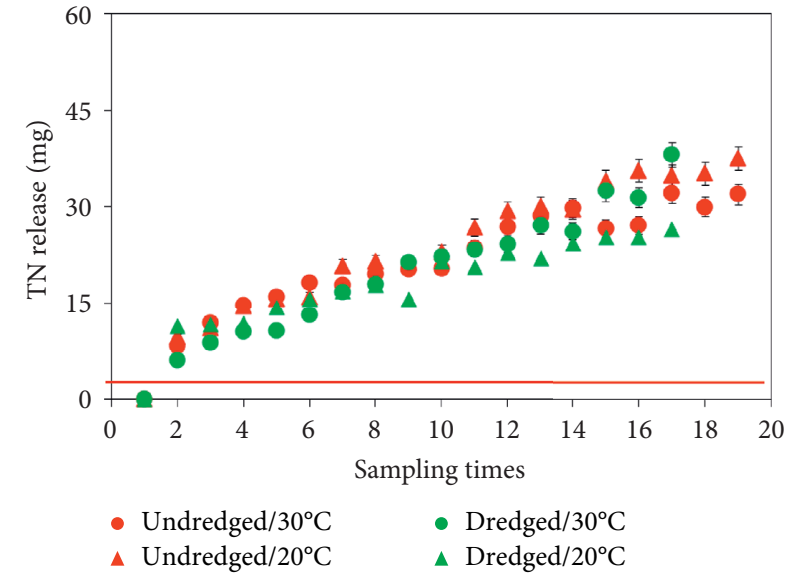

(a)

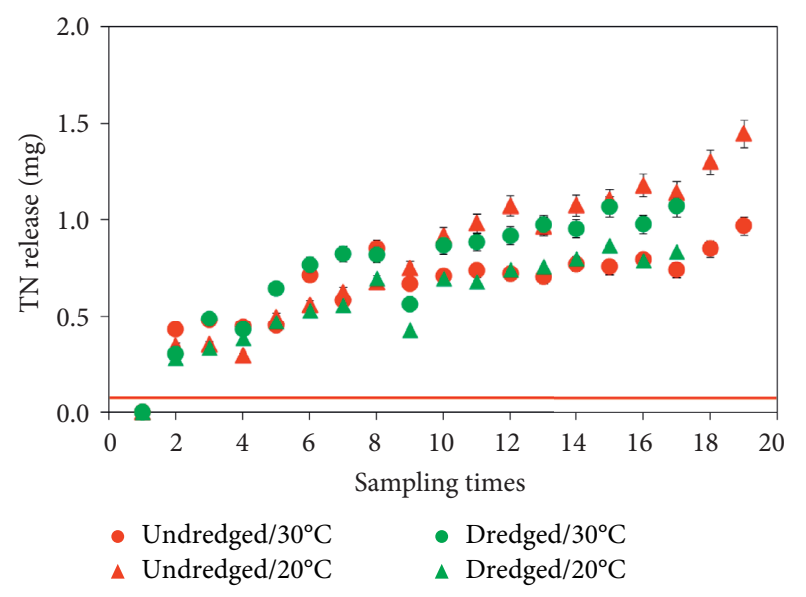

(b)

FIgUre 4: Variation of TN and TP concentrations during dynamic release from dredged and undredged sediments. The solid line is the nutrient concentrations of overlying water in the field.

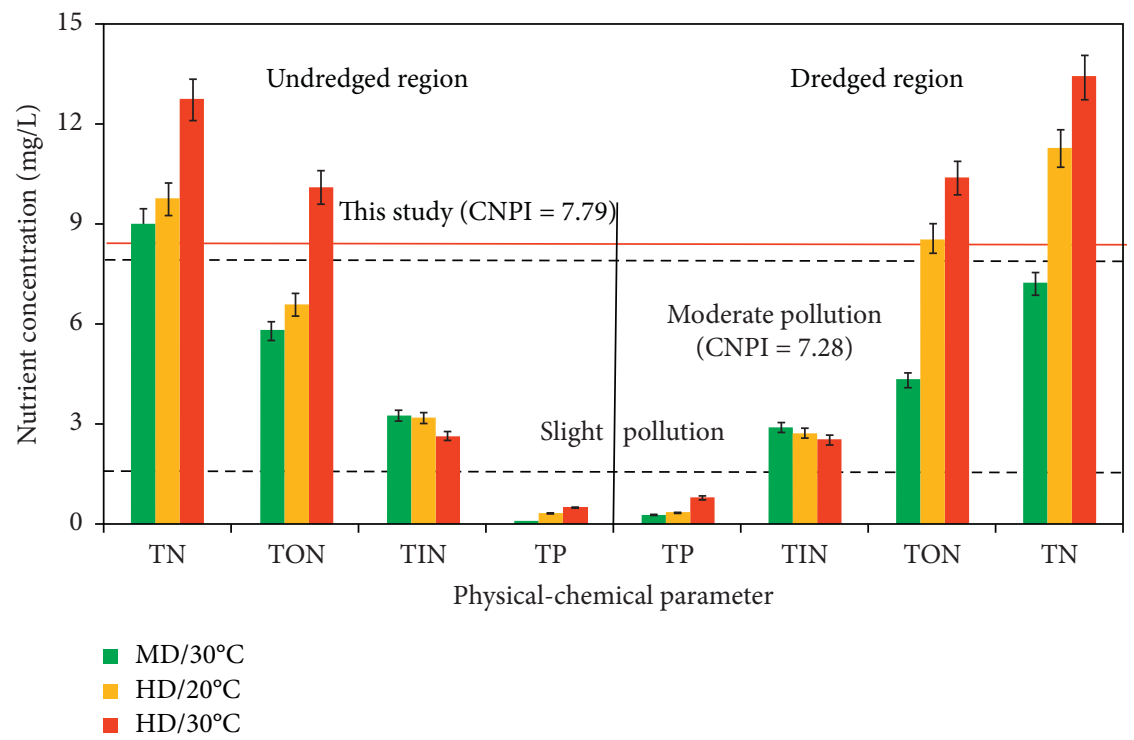

FIgURE 5: Chemical components of the nutrients observed under dynamic release conditions. The dotted lines indicate the slight and moderate pollution levels. The solid line is the pollution risk due to dynamic release (cumulative nutrient concentrations over time), while $\mathrm{MD}$ and $\mathrm{HD}$ are the 90 and $120 \mathrm{r} / \mathrm{min}$ stirring speeds, respectively.

but rather from interstitial water in the early stage of the experiment. Increasing the water temperature may accelerate the transformation of nutrients from organic matter to inorganic substances, especially with regard to $\mathrm{N}$ cycling.

Under the static and dynamic releases, the chemical forms of the released nutrients were obviously affected by the degree of disturbance and temperature variations (Figure 6(b)). In the simulation experiment, the effect of disturbance on nutrient release was mainly expressed as an increase in the rate of physical release. In the short term, nutrients in interstitial water were released into overlying water. Then, disturbance promoted the resuspension of surface sediments and particles. Many nutrients adsorbed on the particles would have been released into overlying water $[2,59]$. However, the effect of increased temperature on nutrient release was mainly apparent as an increase in the rate of chemical release. An increase in temperature may also stimulate microbial activity, accelerating the transformation of organic nutrients into inorganic substances $[60,61]$. However, unlike the effect of disturbance on nutrient release, temperature changes had a certain time lag because of the time necessary for microbes to adapt to the changing environment [41]. For example, in the middle and later stages of the experiments, the dynamic release rate of $\mathrm{TN}$ at $30^{\circ} \mathrm{C}$ was higher than at $20^{\circ} \mathrm{C}$.

In this area, the sediment in the lake region (undredged region) is constantly disturbed by strong wind-wave action. 


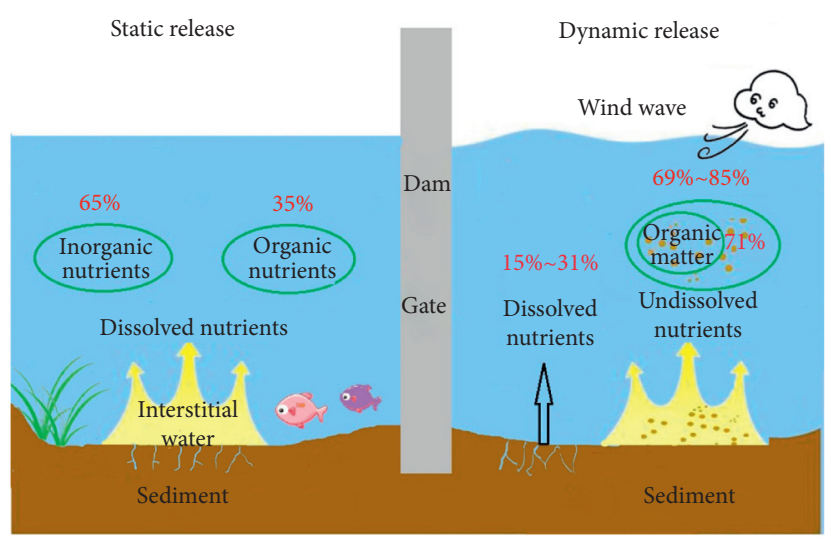

(a)

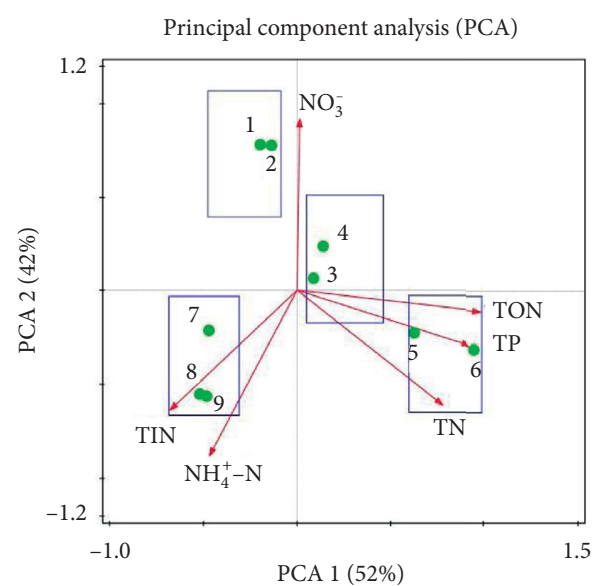

(b)

Figure 6: Characteristics of nutrient release (a) and PCA (b). Numbers 1-9 refer to V1T1, V1T2, V2T1, V2T2, V3T1, V3T2, ST2, MT2, and $\mathrm{BT} 2$, respectively. V1 to V3 are the stirring speeds of 0,90 , and $120 \mathrm{r} / \mathrm{min}$, respectively. T1 and $\mathrm{T} 2$ are the temperatures of 20 and $30^{\circ} \mathrm{C}$, respectively. $M, B$, and $S$ are the sediment depths at $0-15,16-30$, and $31-45 \mathrm{~cm}$, respectively.

Therefore, the internal pollution source has become the main contributor to eutrophication and algal blooms. In the dredged river regions (behind the gate), due to the reduction of wind speed and hydrodynamic forces caused by the gate construction and macrophytes, the sediment in the river regions is barely disturbed by wind-wave action. Static release was considered to be the main form of nutrient release in the dredged regions. Consequently, under stable hydrodynamic conditions (as the dredged region in Table 1), dredging may achieve good eutrophication control results in the long term (more than two years). In contrast, under unstable hydrodynamic and wind-wave conditions (as the undredged region in Table 1), dredging projects may only have short-term positive effects on lake ecosystem health [29].

3.4. Nutrient Releases from Sediments at Different Depths. Although there was a high potential risk of internal release in the dredged region, the water quality in the field was better than that in the undredged region under stable hydrodynamic conditions. This suggested that wave-reduction engineering projects and the construction of artificial aquatic macrophyte communities have effectively reduced sediment disturbances $[13,62]$. Therefore, dredging combined with these measures in the estuary may be an effective method of reducing the potential risk of internal release. However, there may be some negative effects of excessive dredging, limiting the recovery of the natural environment $[63,64]$. Consequently, the depth of dredging may have a profound impact on the restoration of aquatic habitats.

For the same level of disturbance $(120 \mathrm{r} / \mathrm{min})$, the release rate of all nutrients at different depths displayed an upward trend (Figure 7). The average released TDN and TDP loads in the surface $(S)$, middle $(M)$, and bottom $(B)$ sediment were $S_{\mathrm{TDN}}=9.69 \mathrm{mg}, \quad S_{\mathrm{TDP}}=0.13 \mathrm{mg}, \quad M_{\mathrm{TDN}}=14.19 \mathrm{mg}$, $M_{\mathrm{TDP}}=0.12 \mathrm{mg}, B_{\mathrm{TDN}}=14.68 \mathrm{mg}$, and $B_{\mathrm{TDP}}=0.12 \mathrm{mg}$. An analysis of the chemical components revealed that inorganic nutrients were the major components of the dissolved nutrients. The released $\mathrm{NH}_{4}{ }^{+}-\mathrm{N}$ rate in the surface, middle, and bottom sediments accounted for $97 \%, 93 \%$, and $89 \%$ of TDN, respectively. The dynamic release rate of TP was 3.2 times the TDP rate. Undissolved nutrients, which were present as particulate and organic matter, were the main forms of nutrients released by dynamic release.

The observed nutrient release phenomenon at different sediment depths was quite different from that reported in previous studies $[41,65]$. The released TDN rate in the bottom sediment $(14.68 \mathrm{mg})$ exceeded that of the surface $(9.69 \mathrm{mg})$ and middle $(14.19 \mathrm{mg})$ sediment, whereas the TDP release rate was not significantly different at different depths. Previous studies have stated that the nutrient concentration in the surface sediment (i.e., the top $15 \mathrm{~cm}$ ) was higher than in the bottom sediment because the deep sediment is in an anaerobic environment lacking light and oxygen, which is conducive to the denitrification process $[65,66]$. During this transformation process, reactive $\mathrm{N}$ is ultimately released into the atmosphere as gaseous $\mathrm{N}_{2}$, which reduces the $\mathrm{N}$ load in the deep sediment $[41,67]$. The opposite phenomenon was observed here and was possibly caused by the high background concentrations of nutrients identified in the field investigation. Most of the sediments in the estuary areas were either silt or fluid with no obvious sedimentary bedding, suggesting that these sediments may have been deposited over a short period. Thus, there was no obvious stratification of the nutrient concentrations from the surface to the bottom layers. In addition, the sedimentary layers at different depths have been affected by the construction of roads, gates, and bridges. All of these factors may have resulted in the nutrient loading in the bottom sediment being higher than in the surface sediment.

The bottom layer of the sediment had laid in dark, cold, and anaerobic conditions for a long period of time. When the sediments were collected for the laboratory experiment, they received more light, oxygen, and heat. This change in conditions may have stimulated more activity of aerobic 


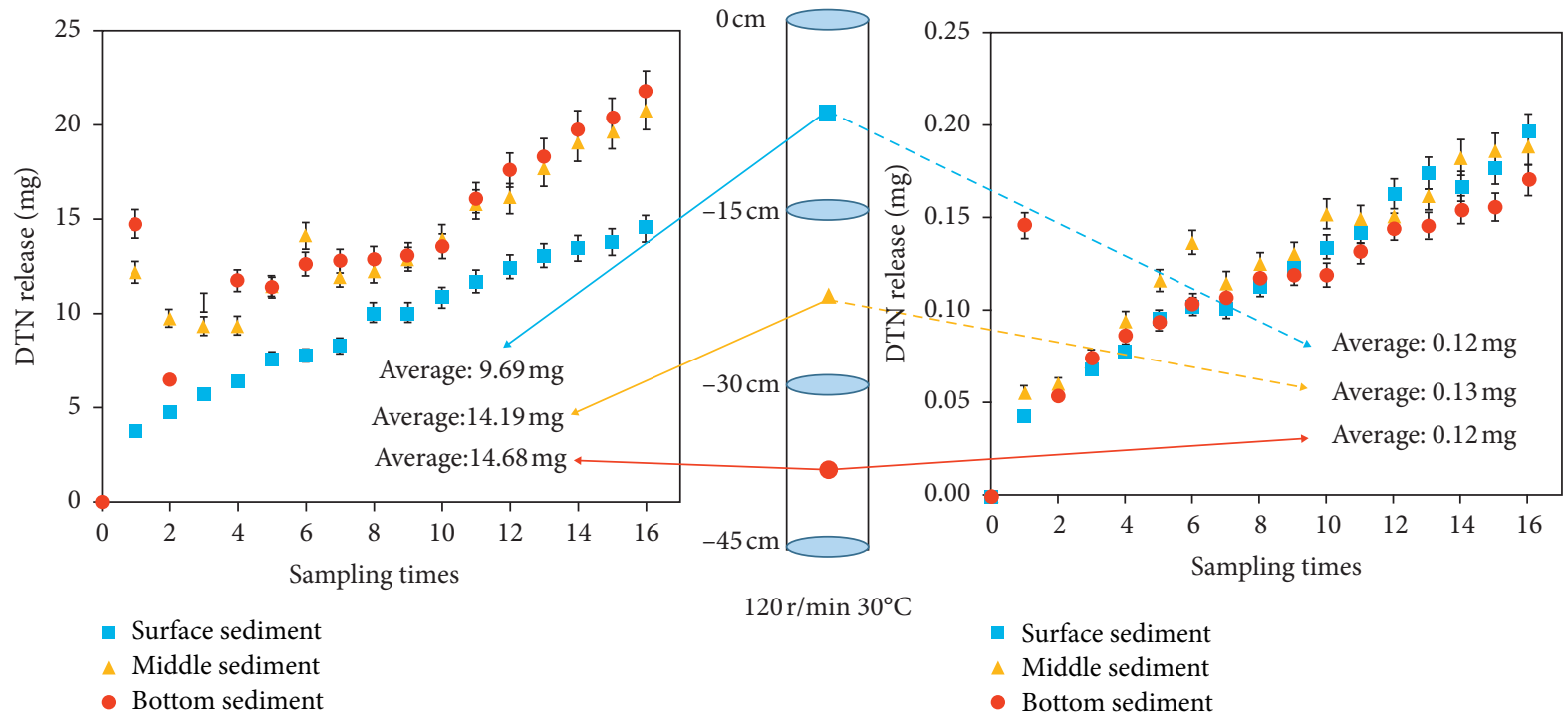

Figure 7: Dynamic release of TDN and TDP at different sediment depths.

microorganisms in the bottom sediment than in the surface sediment, accelerating the transformation of nutrients from organic to inorganic forms $[41,63]$. If so, when the sediment was continuously disturbed in the middle and later stages of the experiment, more inorganic $\mathrm{N}$ was transferred to overlying water from the bottom sediment than from the surface sediment. Due to the continual release of $\mathrm{N}$ and $\mathrm{P}$ from different depths of the sediment, the nutrient concentrations of overlying water far exceeded the eutrophication threshold in this experiment. This result indicated that, in the long term, dredging alone or removing the surface sediment cannot fundamentally solve the problem of internal release under unstable hydrodynamic conditions. In turn, excessive dredging is not beneficial to lake ecosystem health and subsequent restoration measures [27, 29, 33]. Consequently, specific engineering and ecological measures need to be applied in combination with dredging projects in the gate-controlled estuary.

3.5. Response of Water Quality to Dredging. The average release rates of TN and TP (Table 2) from the dredged and undredged sediment were 108.8 and $3.17 \mathrm{mg} /\left(\mathrm{m}^{2} \cdot \mathrm{d}\right)$ and 129.25 and $3.88 \mathrm{mg} /\left(\mathrm{m}^{2} \cdot \mathrm{d}\right)$, respectively. For static release, the pollution levels of surface water in the dredged region were classed as moderate pollution $(\mathrm{CNPI}=1.96)$ and were close to the slight pollution level $(\mathrm{CNPI}=1)$. For dynamic release, the pollution index of surface water $(\mathrm{CNPI}=7.66)$ exceeded the heavy pollution level $(\mathrm{CNPI}>7.28)$ with continuous disturbance. Some of the particulate fractions of $\mathrm{N}$ and $\mathrm{P}$ would settle out under static or breezy conditions, reducing the concentration and net release rates. Compared with the undredged region, the static release rates of TN and TP were 1.2-2.7-fold greater than those in the dredged region. In both dredged and undredged regions, the water pollution levels resulting from dynamic release far exceeded moderate pollution levels. In the field, the water quality improved by $20 \%-30 \%$ following sediment dredging.
Compared with the undredged region, the total nutrient loading of the dredged sediment was reduced by $13 \%-28 \%$. These results indicate that dredging had a better effect on controlling eutrophication under stable hydrodynamic conditions. However, once the waterbodies were disturbed by wind-wave action, the beneficial effect of dredging was greatly reduced. How to reduce sediment disturbance could be the key to aquatic habitat restoration in the future.

Each nutrient release rate from internal release within the estuary region was estimated under different conditions (Table 2). According to the field investigation, the estuary area was approximately $6.87 \mathrm{~km}^{2}$. It is difficult to measure the accurate sediment area through field investigation. To avoid causing uncertainty by estimating the sludge area, we assumed that the distribution of the sediment in the estuary is homogeneous. According to the previous study [68], approximately $44.1 \%$ of the lake area is covered with sludge in Gonghu Bay. Then, the total loads of internal nutrient releases would be calculated. Under the static and dynamic releases, the total loads released from the sediment to the waterbodies were 62.66 and $1.01 \mathrm{t} / \mathrm{a}$, respectively, for TN, and 199.79 and $6.77 \mathrm{t} / \mathrm{a}$, respectively, for TP. Approximately $222.04 \mathrm{t} / \mathrm{a}$ of TN load was discharged from external pollution sources (e.g., agriculture, industry, domestic sewage, and atmospheric $\mathrm{N}$ deposition). In this simulation experiment, the TN load from internal pollution is close to external pollution, accounting for $89.98 \%$. More sediment would accumulate in the estuarine zones if the gate was closed permanently. The contribution of the internal release from the sediment could have a significant potential risk for water quality degradation. Internal release would become a crucial issue for eutrophication in this estuary region in the future. This suggests that if the sediment was constantly disturbed under unstable hydrodynamic conditions and wind-wave action, more attention, as same as controlling the external pollutant input, should be given to the effects of internal pollution on the estuarine aquatic habitat in future environmental restoration. 
TABLE 2: TN and TP concentrations and release rates and CNPI values.

\begin{tabular}{|c|c|c|c|c|c|c|}
\hline & & \multicolumn{2}{|c|}{ Concentrations (mg/L) } & \multicolumn{2}{|c|}{ Release rate $\left(\mathrm{mg} /\left(\mathrm{m}^{2} \cdot \mathrm{d}\right)\right)$} & \multirow{2}{*}{$\begin{array}{c}\text { Pollution risk } \\
\text { CNPI }\end{array}$} \\
\hline & & $\mathrm{TN}$ & $\mathrm{TP}$ & $\mathrm{TN}$ & $\mathrm{TP}$ & \\
\hline \multirow{2}{*}{ Dredged } & SR & $1.67-6.32$ & $0.01-0.07$ & 51.42 & 0.50 & 1.96 \\
\hline & DR & $3.31-21.04$ & $0.05-1.23$ & 164.75 & 5.83 & 7.01 \\
\hline \multirow{2}{*}{ Undredged } & SR & $2.24-5.98$ & $0.03-0.15$ & 61.92 & 1.33 & 2.39 \\
\hline & DR & $5.28-16.69$ & $0.05-0.52$ & 196.58 & 6.42 & 7.66 \\
\hline \multirow{2}{*}{ All samples } & SR & $3.00 \pm 0.54$ & $0.06 \pm 0.04$ & $56.67 \pm 7.42$ & $0.92 \pm 0.59$ & $2.34 \pm 0.08$ \\
\hline & $\mathrm{DR}$ & $9.93 \pm 0.75$ & $0.31 \pm 0.05$ & $180.67 \pm 22.51$ & $6.13 \pm 0.41$ & $7.34 \pm 0.46$ \\
\hline
\end{tabular}

Note: SR and DR are the static releases and dynamic releases, respectively.

3.6. Implications for Estuary Restoration. Previous studies have shown that the efficacy of sediment dredging is affected by multiple factors, such as the available technology, operation time, hydrodynamic conditions, gate construction, dredging scope, and depth of dredging [27-29]. Dredging may disturb natural biogeochemical processes. For example, the biological activity of denitrifying bacteria is decreased when the surface sediment is removed $[65,66,69]$. The bottom layer receives more oxygen and light, which is not conducive to the denitrification process. Therefore, sediment dredging may reduce the rate of denitrification, which has a negative effect on eutrophic governance. Because the environmental conditions of the sediments are changed by dredging, the diversity of zoobenthos may decrease, with potential food web and nutrient cycling ramifications $[70,71]$. For example, aquatic plants provide a refuge for benthos from fish predation, but large areas of aquatic plants are removed when the sediment is dredged. Zoobenthos and zooplankton would then be more likely to be preyed on by fish because the disappearance of phytoplankton would reduce their natural food source. Therefore, we need to fully understand the habitat characteristics and negative impacts of sediment dredging in this study area.

In the field investigation, an inhomogeneous distribution of sediment was observed in the estuary. In some areas, the ooze thickness was more than $45 \mathrm{~cm}$. In other areas, there was no ooze, and the lake bed was hard. It is impossible to dredge all of the top $45 \mathrm{~cm}$ layers of the sediment in the estuary. To minimize the negative impact of excessive dredging on the aquatic habitat, it is first necessary to conduct a comprehensive investigation of sediment depth and distribution in the estuary. Then, based on the results of the simulation experiments and the proposed guidelines for dredging projects in China [28], it is suggested that the top $30 \mathrm{~cm}$ of fluid mud and the layer with a high nutrient loading should be dredged. In the areas of hard sediment, there is no need for dredging. Given that the risk of nutrient release is greater at $30^{\circ} \mathrm{C}$ than at $20^{\circ} \mathrm{C}$, winter and autumn may be the optimal times for sediment dredging in the estuary to minimize the negative impact on the aquatic habitat.

Dredging alone may be insufficient to restore the aquatic habitat over the long term. Eutrophication and water quality degradation are ecological issues that should be solved using ecological methods $[29,34]$. In the study area, the biological buffer zone along the river bank was still preserved in the dredged regions. However, there were almost no submerged plants and emergent plants growing in the riverbed. The buffer zone can reduce the external nutrient discharged into the river, but cannot control the potential risk of internal releases of nutrients from the sediment. These considerations indicate that more biological measures are required. For example, aquatic plant communities should be planted in the river course and lake areas rather than merely being added to the biological buffers along the lakeshore or riverbank. Under stable hydrodynamic conditions, dredging combined with biological measures may enable effective ecological restoration to be achieved. However, under unstable hydrodynamic conditions, additional measures, such as wave-reduction engineering projects, should be considered to reduce sediment disturbance.

\section{Conclusions}

In this study, a laboratory experiment was conducted to simulate nutrient release in dredged and undredged regions of a gate-controlled estuary. Significant differences in the nutrient release characteristics of static and dynamic releases were noted. In a static release, the main form of released nutrients was dissolved matter, whereas undissolved matter was the main form of nutrients in a dynamic release. At high temperatures $\left(30^{\circ} \mathrm{C}\right)$, the release rate from the bottom sediment exceeded that from the surface sediment. This indicated that a high risk of nutrient release still remained when the surface sediment was removed. A gate has a profound impact on nutrient release by changing the hydrodynamic conditions.

Over the past seven years, under stable hydrodynamic conditions, dredging has had a long-term effectiveness in controlling eutrophication. However, when sediments were usually disturbed by wind-wave action, both dredged and undredged regions had a high risk of nutrient release. Consequently, under unstable hydrodynamic conditions, simply dredging the surface sediment does not reduce the risk of internal nutrient release and will increase eutrophication levels in the long term.

To minimize the potential risk of internal nutrient release in the gate-controlled estuary of northern Taihu Lake, it is suggested that, as in many other gate-controlled estuaries worldwide, external pollution sources should be intercepted before or after sediment dredging. To maintain the effectiveness of estuary habitat restoration, specific biological measures should be combined with engineering measures to 
reduce sediment disturbance and restore the aquatic habitat under unstable hydrodynamic conditions.

Ultrapure water was used in this experiment which could make the difference of nutrient release more significant than overlying water in nature. This can help us to understand the mechanism of nutrient release responding to disturbance and temperature variation, but it is different from the natural condition. It may result in more nutrients released than what would be observed in nature. Thus, in future research, it is important to combine with the in situ experiment to help us better reveal the mechanism of nutrient release.

\section{Data Availability}

The data used to support the findings of this study are available from the corresponding author upon request.

\section{Conflicts of Interest}

The authors declare that there are no conflicts of interest regarding the publication of this paper.

\section{Acknowledgments}

This work was supported by the National Natural Science Foundation of China (41673107), Major Project of Jiangsu Provincial Department of Education (20KJA170001), the National Water Pollution Control and Treatment Science and Technology Major Project (2017ZX07203-005), and PAPD (164320H116).

\section{Supplementary Materials}

Table S1: factor selection and experimental design. Table S2: two-way repeated measures ANOVA of nutrient release responding to disturbance and temperature variation. Table S3: the classifications of water quality based on the Nemerow pollution index (CNPI). Figure S1: field investigation of dredged and undredged regions and different types of dams and gates. (Supplementary Materials)

\section{References}

[1] J. Bloesch, "A review of methods used to measure sediment resuspension," Hydrobiologia, vol. 284, no. 1, pp. 13-18, 1994.

[2] B. Qin and G. Zhu, "The nutrient forms, cycling and exchange flux in the sediment and overlying water system in lakes from the middle and lower reaches of Yangtze River," Science in China Series D, vol. 49, no. S1, pp. 1-13, 2006.

[3] J. J. Wang, Y. Pang, Y. P. Li, Y. W. Huang, and J. Luo, "Experimental study of wind-induced sediment suspension and nutrient release in Meiliang Bay of Lake Taihu, China," Environmental Science Pollution Research, vol. 22, pp. 104710479, 2015.

[4] P. Gelencsér, F. Szilágyi, L. Somlyody, and L. Lijklema, “A study on the influence of sediment in the phosphorus cycle in Lake Balaton," Collaborative Paper, pp. 1-72, 1982.

[5] M. Søndergaard, P. J. Jensen, and E. Eppesen, "Role of sediment and internal loading of phosphorus in shallow lakes," Hydrobiologia, vol. 506, pp. 135-145, 2003.
[6] C. Li, H. Yu, S. Tabassum et al., "Effect of calcium silicate hydrates coupled with Myriophyllum spicatum on phosphorus release and immobilization in shallow lake sediment," Chemical Engineering Journal, vol. 331, pp. 462-470, 2018.

[7] K. S. Pfenning and P. B. McMahon, "Effect of nitrate, organic carbon, and temperature on potential denitrification rates in nitrate-rich riverbed sediments," Journal of Hydrology, vol. 187, no. 3-4, pp. 283-295, 1997.

[8] V. P. Percuoco, L. H. Kalnejais, and L. V. Officer, "Nutrient release from the sediments of the great bay estuary, N.H. USA," Estuarine, Coastal and Shelf Science, vol. 161, pp. 76-87, 2015.

[9] X. Chen, Y. Wang, Z. Cai, C. Wu, and C. Ye, "Effects of landuse and land-cover change on nitrogen transport in northern Taihu basin, China during 1990-2017," Sustainability, vol. 12, no. 9, p. 3895, 2020.

[10] T. Wu, B. Qin, G. Zhu et al., "Flume simulation of waveinduced release of internal dissolved nitrogen in Taihu Lake, China," Chinese Journal of Oceanology and Limnology, vol. 30, no. 5, pp. 796-805, 2012.

[11] Y. Zhang, C. Tang, J. Wang et al., "Effect of wave-current interactions on sediment resuspension in large shallow Lake Taihu, China," Environmental Science and Pollution Research, vol. 24, no. 4, pp. 4029-4039, 2017.

[12] A. D. Luo and B. M. Spears, Internal Phosphorus Loading in Lakes: Causes, Case Studies, and Management, J Ross Publishing, Fort Lauderdale, FL, USA, 2020.

[13] P. Huang and Z. Liu, "The effect of wave-reduction engineering on sediment resuspension in a large, shallow, eutrophic lake (Lake Taihu)," Ecological Engineering, vol. 35, no. 11, pp. 1619-1623, 2009.

[14] K. E. Havens, T. Fukushima, P. Xie et al., "Nutrient dynamics and the eutrophication of shallow lakes Kasumigaura (Japan), Donghu (PR China), and Okeechobee (USA)," Environmental Pollution, vol. 111, no. 2, pp. 263-272, 2001.

[15] M. Hanazato, Ecology of Shallow Lakes, Chapman \& Hall, London, UK, 1997.

[16] M. Sondergaard, P. J. Jensen, and E. Jeppesen, "Retention and internal loading of phosphorus in shallow, eutrophic lakes," The Scientific World Journal, vol. 1, pp. 427-442, 2001.

[17] B. Qin, "Lake eutrophication: control countermeasures and recycling exploitation," Ecological Engineering, vol. 35, no. 11, pp. 1569-1573, 2009.

[18] Y. Yuan, H. Wei, L. Zhao, and Y. Cao, "Implications of intermittent turbulent bursts for sediment resuspension in a coastal bottom boundary layer: a field study in the western Yellow Sea, China," Marine Geology, vol. 263, no. 1-4, pp. 87-96, 2009.

[19] C. X. Fan, L. Zhang, and W. C. Qu, "Lake sediment resuspension and caused phosphate release-a simulation study," Journal Environmental Science, vol. 13, pp. 406-410, 2001.

[20] K. R. Reddy, M. M. Fisher, and D. Ivanoff, "Resuspension and diffusive flux of nitrogen and phosphorus in a hypereutrophic lake," Journal of Environmental Quality, vol. 25, no. 2, pp. 363-371, 1996.

[21] K. M. Gertrud, D. L. Bruce, S. L. Pei, and A. M. Lewis, "Quantification of internal phosphorus load in large, partially polymictic and mesotrophic Lake Simcoe Ontario," Journal of Great Lakes Research, vol. 39, pp. 271-279, 2013.

[22] Z. Wu, Y. Liu, Z. Liang, S. Wu, and H. Guo, "Internal cycling, not external loading, decides the nutrient limitation in eutrophic lake: a dynamic model with temporal Bayesian hierarchical inference," Water Research, vol. 116, pp. 231-240, 2017. 
[23] S. Ding, M. Chen, M. Gong et al., "Internal phosphorus loading from sediments causes seasonal nitrogen limitation for harmful algal blooms," Science of the Total Environment, vol. 625, pp. 872-884, 2018.

[24] W. A. Gao, H. W. Paerl, and W. K. Dodds, "Nutrients, eutrophication and harmful algal blooms along the freshwater to marine continuum," Wiley Interdisciplinary Reviews, vol. 6, Article ID e1373, 2019.

[25] C. X. Fan, "Preliminary stud y on the evaluation of sludgedredging work in Lake Kasumigaura using large size core samples," in Proceedings of VI Conference on Conservation and Management of Lakes, Kasumigaura, November 1995.

[26] K. L. Spencer, R. E. Dewhurst, and P. Penna, "Potential impacts of water injection dredging on water quality and ecotoxicity in Limehouse Basin, River Thames, SE England, UK," Chemosphere, vol. 63, p. 521, 2006.

[27] C. Fan, L. Zhang, B. Q. Qin, S. M. Wang, and W. P. Hu, "Estimation on dynamic release of phosphorus from windinduced suspended particulate matter in Lake Taihu," Science in China Series D, vol. 47, no. 8, pp. 710-719, 2004.

[28] X. C. Jin, J. J. Li, and Q. B. Zhang, Technical Guide for Environmental Dredging of Lakes and Rivers, Science Press, China, 2013.

[29] L. Jing, S. Bai, Y. Li et al., "Dredging project caused short-term positive effects on lake ecosystem health: a five-year follow-up study at the integrated lake ecosystem level," Science of The Total Environment, vol. 686, pp. 753-763, 2019.

[30] X. Y. Liu, C. H. Wang, C. R. Yu, L. Wen, and P. Y. Duan, "Characteristics of sediments and nutrient release under different flow velocity," Acta Scientiae Circumstantiae, vol. 37, pp. 2862-2869, 2017.

[31] J. Yu, S. Ding, J. Zhong et al., "Evaluation of simulated dredging to control internal phosphorus release from sediments: focused on phosphorus transfer and resupply across the sediment-water interface," Science of the Total Environment, vol. 592, pp. 662-673, 2017.

[32] J. Zhang, C. Fan, J. Zhong et al., "Effects of sediment dredging on nitrogen cycling in Lake Taihu, China: insight from mass balance based on a 2-year field study," Environmental Science and Pollution Research, vol. 23, no. 4, pp. 3871-3883, 2016.

[33] K. E. Gustavson, G. A. Burton, N. R. Francingues, D. D. Reible, D. J. Vorhees, and J. R. Wolfe, "Evaluating the effectiveness of contaminated-sediment dredging," Environmental Science \& Technology, vol. 42, no. 14, pp. 5042-5047, 2008.

[34] P. M. Pu, G. X. Wang, C. H. Hu, W. P. Hu, and C. X. Fan, "Can we control lake eutrophication by dredging? (In Chinese)," Journal of Lake Science, vol. 12, pp. 269-279, 2000.

[35] H. Yang, G. Wang, L. Wang, and B. Zheng, "Impact of land use changes on water quality in headwaters of the Three Gorges Reservoir," Environmental Science and Pollution Research, vol. 23, no. 12, pp. 11448-11460, 2015.

[36] G. Wei, Z. Yang, B. Cui et al., "Impact of dam construction on water quality and water self-purification capacity of the Lancang River, China," Water Resources Management, vol. 23, no. 9, pp. 1763-1780, 2009.

[37] Y.-F. Guan, J.-Z. Wang, H.-G. Ni, and E. Y. Zeng, “Organochlorine pesticides and polychlorinated biphenyls in riverine runoff of the Pearl River Delta, China: assessment of mass loading, input source and environmental fate," Environmental Pollution, vol. 157, no. 2, pp. 618-624, 2009.

[38] X. H. Zhou, L. M. Liu, X. Chen, Z. G. Chen, J. P. Zhang, and B. Liu, "Heavy metals distribution characteristics and ecological risk evaluation in surface sediments of dammed Jinshan Lake (In Chinese)," Environmental Science, vol. 35, pp. 4127-4134, 2014.

[39] H. W. Paerl, "Nuisance phytoplankton blooms in coastal, estuarine and inland waters," Limnology and Oceanography, vol. 33, pp. 823-847, 1998.

[40] R. Zhang, D. Jiang, L. Zhang, Y. Cui, M. Li, and L. Xiao, "Distribution of nutrients, heavy metals, and PAHs affected by sediment dredging in the Wujin'gang River basin flowing into Meiliang Bay of Lake Taihu," Environmental Science and Pollution Research, vol. 21, no. 3, pp. 2141-2153, 2014.

[41] X. Xia, S. Zhang, S. Li et al., "The cycle of nitrogen in river systems: sources, transformation, and flux," Environmental Science: Processes \& Impacts, vol. 20, no. 6, pp. 863-891, 2018.

[42] "Taihu basin authority of ministry of water resources, China," 2019, http://www.tba.gov.cn/.

[43] E. A. Dilek, L. C. Luo, and P. H. David, "Temporal and spatial trends in water quality of Lake Taihu, China: analysis from a north to mid-lake transect, 1991-2011," Environmental Monitoring and Assessment, vol. 186, pp. 3891-3904, 2014.

[44] B. Xue, S. Yao, and W. Xia, "Environmental changes in Lake Taihu during the past century as recorded in sediment cores," Hydrobiologia, vol. 581, no. 1, pp. 117-123, 2007.

[45] R. Stone, "China aims to turn tide against toxic lake pollution," Science, vol. 333, no. 6047, pp. 1210-1211, 2011.

[46] B. Qin, H. W. Paerl, J. D. Brookes et al., "Why Lake Taihu continues to be plagued with cyanobacterial blooms through 10 years (2007-2017) efforts," Science Bulletin, vol. 64, no. 6, pp. 354-356, 2019.

[47] H. Y. Wang, "Discussion on ecological dredging and silt treatment technology of Taihu Lake in Wuxi city," Engineering Science, vol. 12, pp. 108-112, 2010.

[48] National Environmental Protection Administration (NEPA), Water and Wastewater Monitoring Methods, Environmental Science Press, Beijing, China, 2002.

[49] A. Gasith, "Tripton Sedimentation in eutrophic lakes-simple correction for the resuspended matter," SIL Proceedings, vol. 19, no. 1, pp. 116-122, 1975.

[50] X. Chen, Y. Wang, Z. Cai, M. Zhang, and C. Ye, "Response of the nitrogen load and its driving forces in estuarine water to dam construction in Taihu Lake, China," Environmental Science and Pollution Research, vol. 27, no. 25, pp. 3145831467, 2020.

[51] Y. Yang, Q. G. Liu, Z. J. Hu, Y. M. Zhang, and Y. X. Gao, "Spatial distribution of sediment carbon, nitrogen and phosphorus and pollution evaluation of sediment in Taihu Lake Basin (In Chinese)," Acta Scientiae Circumstantiae, vol. 34, pp. 3057-3064, 2014.

[52] H. Y. Guo, X. R. Wang, and J. G. Zhu, "Quantification and index of non-point source pollution in Taihu Lake region with GIS," Environmental Geochemistry and Health, vol. 26, no. 2, pp. 147-156, 2004.

[53] P. J. Johns and P. E. O'sullivan, "The natural history of Slapton Ley Nature Research XVIII: nitrogen and phosphorus losses from the catchment-an export coefficient approach," Field Studies, vol. 7, pp. 285-309, 1989.

[54] M. J. Shim, Y. M. Yang, D. Y. Oh et al., "Spatial distribution of heavy metal accumulation in the sediments after dam construction," Environmental Monitoring Assessment, vol. 187, no. 1-14, p. 733, 2015.

[55] M. M. Bahar, H. Ohmori, and M. Yamamuro, "Relationship between river water quality and land use in a small river basin running through the urbanizing area of Central Japan," Limnology, vol. 9, no. 1, pp. 19-26, 2008. 
[56] Z. Shen, X. Hou, W. Li, G. Aini, L. Chen, and Y. Gong, "Impact of landscape pattern at multiple spatial scales on water quality: a case study in a typical urbanised watershed in China," Ecological Indicators, vol. 48, pp. 417-427, 2015.

[57] K. N. Aini, P. P. Ouseph, and D. Padmalal, "Interstitial water sediment geochemistry of $\mathrm{N}, \mathrm{P}$ and $\mathrm{Fe}$ and its response to overlying waters of tropical estuaries: a case from the southwest coast of India," Environmental Geology, vol. 39, no. 6, pp. 633-640, 2000.

[58] D. E. Canfield, E. Kristensen, and B. Thamdrup, Aquatic GeoMicrobiology, Gulf Professional Publishing, Amsterdam, Netherlands, 2005.

[59] N. Xia, X. Xia, T. Liu et al., "Characteristics of bacterial community in the water and surface sediment of the Yellow River, China, the largest turbid river in the world," Journal of Soils and Sediments, vol. 14, no. 11, pp. 1894-1904, 2014.

[60] K. S. Hu, V. Bouchard, and R. H. Moore, "Factors affecting denitrification in agricultural headwater streams in Northeast Ohio, USA," Hydrobiologia, vol. 598, no. 1, pp. 305-314, 2008.

[61] M. A. H. J. Van Kessel, D. R. Speth, M. Albertsen et al., "Complete nitrification by a single microorganism," Nature, vol. 528, no. 7583, pp. 555-559, 2015.

[62] T. L. Nielsen, C. Mitraki, and G. Zalidis, "Integrating vertical and horizontal approaches for management of shallow lakes and wetlands," Ecological Engineering, vol. 24, no. 4, pp. 379-389, 2005.

[63] K. R. Reddy, M. M. Fisher, Y. Wang, J. R. White, and T. James, "Potential effects of sediment dredging on internal phosphorus loading in a shallow, subtropical lake," Lake and Reservoir Management, vol. 23, no. 1, pp. 27-38, 2007.

[64] M. James, E. Jeppesen, T. L. Lauridsen et al., "Lake restoration: successes, failures and long-term effects," Journal of Applied Ecology, vol. 44, no. 6, pp. 1095-1105, 2007.

[65] J. N. Skov, F. J. Dentener, D. G. Capone et al., "Nitrogen cycles: past, present, and future," Biogeochemistry, vol. 70, no. 2, pp. 153-226, 2004.

[66] B. Boyer, "New pathways and processes in the global nitrogen cycle," Annual Review of Ecology, Evolution, and Systematics, vol. 43, no. 1, pp. 407-428, 2012.

[67] L. A. Robertson and J. G. Kuenen, "Aerobic denitrification: a controversy revived," Archives of Microbiology, vol. 139, no. 4, pp. 351-354, 1984.

[68] C. X. Fan, Y. B. Liu, and H. S. Chen, "Approach on estimating storage sludge in Lake Taihu and its distributing characteristics,” Shanghai Environ Sci, vol. 19, pp. 72-75, 2000.

[69] J. Zhong, C. Fan, L. Zhang et al., "Significance of dredging on sediment denitrification in Meiliang Bay, China: a year long simulation study," Journal of Environmental Sciences, vol. 22, no. 1, pp. 68-75, 2010.

[70] R. Kornijw, K. Vakkilainen, J. Horppila, E. Luokkanen, and T. Kairesalo, "Impacts of a submerged plant (Elodea Canadensis) on interactions between roach (Rutilus rutilus) and its invertebrate prey communities in a lake littoral zone," Freshwater Biology, vol. 50, pp. 262-276, 2005.

[71] A. J. Kenny and H. L. Rees, "The effects of marine gravel extraction on the macrobenthos: results 2 years post-dredging," Marine Pollution Bulletin, vol. 32, no. 8-9, pp. 615-622, 1996. 